\title{
Determinants of Productivity and Profitability of Indian Banking Sector: A Comparative Study
}

\author{
Karam Pal NARWAL*, Shweta PATHNEJA**
}

\begin{abstract}
The purpose of this paper is to discuss the different determinants of productivity and profitability of banks functioning in India. The performance of public and private sector banks in terms of productivity and profitability is being assessed in two different time periods (2003-04 to 2008-09 and 2009-10 to 2013-2014). The linear programming model Data Envelopment Analysis (DEA) based Malmquist index is used to measure total factor productivity of groups and sub-group banks. The decomposition of total factor productivity into pure technical and scale efficiency is done to get a comprehensive insight of the effect of these two on the overall productivity. Further, regression analysis discovers the determinants of different bank groups. The results of the study disclose that private sector banks are more productive than public sector banks over the whole study period. But no significant difference exists in the profitability of two bank groups. The main reason of more productivity of private sector banks is the better utilization of technology than the public sector banks. Further, the productivity of banking sector of India is not found significantly different in the two sub-periods although the banks have performed better in the sub-period II (2009-10 to 2013-14).
\end{abstract}

Keywords: Productivity, Performance, Profitability, Banks, Ownership, India.

JEL Classification: C14, C23, G21

UDC: $336.71(540)$

\footnotetext{
*Professor in Finance, Haryana School of Business, Guru Jambheshwar University of Science and Technology, Hisar (Haryana), India. E-mail: karampalhsb@gmail.com.

${ }^{* *}$ Corresponding Author), Assistant Professor in Finance, National Institute of Technology (NIT), Kurukshetra, India. E-mail: shwetapathneja@gmail.com.
} 


\section{Introduction}

The banking sector is considered as one of the leading contributors to the growth of an economy. It is termed as the primary engine of growth an economy. This sector has experienced a complete transformation over the years across the globe. The banking institutions throughout the world are facing a fast paced dynamic environment where efficiency and competitiveness hold the key to survival (Mukherjee et al., 2002). According to Hanif Akhtar (2010), Globalization, deregulation, financial innovation and automation have been the major forces leaving their impact on performance of the banking sector. Due to its major contribution towards the overall growth of a country it becomes important to gauge the performance of this sector in terms of productivity and profitability on continuous basis. As per the study of Ramakrishnan (2007), the banking sector is one of the most important sectors in an economy, and the importance of adequately measuring the performance of banks has been recognized for a long time. Further, the increased competition with advanced technology has changed the overall set-up of this sector. Cost minimization, increased productivity and profitability with customer satisfaction are some of the major challenges of this sector in the present scenario. According to Chatzoglou et al., (2010), in the frame of the technological and financial progress, it is important for banks to develop and implement a high productivity policy, which, ultimately, leads to high profitability.

India is an imperative market as far as banking is concerned. It is also grabbing the attention, not only due to its utter size, but also because of extensive changes the sector has witnessed in the last two decades. The process of reforms in this sector, as a part of structured economic reforms, started in 1992 with the initiation by Narasimham Committee Report. Further, the development of technology in the sector made it more globalised and competitive. As per the study of Barman (2007), the declining tendency in Herfindahl's Concentration Index and net-interest margin (i.e. interest spread) during the post-reforms period bear the witness that over the years, competition in the Indian banking sector has increased significantly.

Further, the terms productivity and performance are commonly used within academic and commercial circles, they are, however, rarely and adequately defined or explained (Tangen, 2004). Productivity is termed as efficient use of resources to achieve the set targets. Some defined it as a ratio of output produced with the input used (Heizar \& Rainder 1996). Being a service provider banks use different kind of inputs to produce outputs. The main problem with measuring bank productivity is that, it is difficult to define, as there are many factors that should be estimated, and it can be measured by output, cost, efficiency and performance (Chatzoglou et al, 2010.). Further, different methods like ratio analysis, parametric and non-parametric frontier approaches are applied to study the performance of banking sector in the banking literature. Today's competitive banking environment has heightened the need for methods to evaluate the risks and returns involved in banking (Yeh, 1996). The present study utilizes the non-parametric Data 
Envelopment Analysis (DEA) based Malmquist Productivity Index (MPI) to measure the productivity of banks over the years as DEA is the most frequently accepted approach to assess the banking productivity over the years. The result of the review study by Sharma et al. (2012) reveals that 75 percent of reviewing studies apply DEA to assess the efficiency and productivity of the banking sector. Ramanathan (2003) and Casu et al. (2004) also considered DEA as a major tool to measure the total factor productivity of banks in their study. Productivity and profitability both are equally important for a bank to survive and to increase its scale of business in order to achieve the ultimate objective of growth. As mentioned above, productivity is the ratio of output to the input used, whereas, profitability is related to the business operations of the banks and considered as an important prerequisite for both growth and survival.

So, the present study makes an attempt to measure the productivity and profitability of Indian banking sector over the past ten years (2004-05 to 2013-14). Although, a vast literature is available on the efficiency analysis of banking sector of different countries with India is no exception, the present study tries to extend the existing literature in the following ways:

Firstly, the present study simultaneously assess the productivity and profitability of the banking sector over the years, as no study in the studied literature is found which evaluate the both aspects together in one study. Secondly, the study time period (2004-05 to 2013-14) is divided into two sub periods i.e. 2004-05 to 2008-09 and 2009-10 to 2013-14 to compare the productivity and profitability of banks in these two different time periods. The another facet of division of this time period is that the world economy was recovering from the phase of sub-prime crisis of 2009, so, it may be more meaningful to study the productivity and profitability over these two sub-periods. Lastly, the performance difference in terms of productivity and profitability of public and private sector banks is also measured as these two together cover more than $90 \%$ of the banking business in India.

The study further proceeds as follows. The $2^{\text {nd }}$ section reviews the existing studies in terms of productivity and profitability of banks. The $3^{\text {rd }}$ section provides a brief of the methodology used in the present study. The $4^{\text {th }}$ section discloses the results and the interpretation of results thereof. The $5^{\text {th }}$ section concludes the paper and the last section gives policy implications and future research prospects in which future studies may be extended.

\section{Literature Review}

Prior literature emphasizes on either bank's productivity or profitability. There are numerous studies which focus their analysis on the bank productivity of different countries. Like, Tina Zhang and Wang (2014) on Chinese banks; Rezitis (2006) and Chatzoglou et al. (2010) on Greek banks; Ataullah and Le (2006), Kumar and Gulati (2008), Das (2010), and Kumar and Gulati (2010) for Indian banks; Berger and 
Mester (1999), and Elyasiani and Mehdian (1990) for U. S. banks; Sathye (2002) for Australian banks are some notable studies amongst others. Also, there are studies on profitability analysis of banks by different researchers like Ho and Tripe (2002); Guru et al. (2002); DeYoung and Rice (2004); Haung and Chen (2006) and Pasiouras and Kosmidou (2007). Some of the studies on productivity and profitability aspects are reviewed in this section.

\subsection{Productivity analysis of banks}

Bhatia and Mahendru (2015) examined the efficiency of public sector banks in India and observed a significant difference in the performance of banks in pre and postreformatory era. Tina Zhang and Wang (2014) investigated the productive efficiency of Chinese banks with the help of DEA and MPI and observed that public sector banks in China are less efficient than private sector banks. Also, the main reason of inefficiency was found to be scale rather than pure technical inefficiency. Arjomandi et al. (2012) analyzed the efficiency and productivity of banks in Iran and observed a downfall in productivity after the introduction of regulatory changes. In another study by Wahab and Rahim Abdul Rahman (2012) for Malysian banks the total factor productivity was found improved by $2.4 \%$ and the main cause of this increase was attributed to technological advancement of banks during the study period. Chatzoglou et al. (2010) measured the productivity of Greek banks and found a constant performance of banks over the study period. Yet, a positive relation between size and banks performance was observed. Further, the study concluded that if two or more small banks are merged it may make banks more efficient and productive. The effect of financial reforms for Taiwan banks was found to be favorable in the study of Huang et al. (2008) as a phenomenal increase of $117.39 \%$ was observed after the introduction of reforms and this increase was mainly due to technical efficiency rather technological change. Further, Kumar and Gulati (2008) evaluated the efficiency of Indian public sector and found only 7 fully efficient banks out of 27 public sector banks. Further, SBI group outperforms the other nationalized banks during the study period. The regression results incisively indicate that the exposure to off-balance sheet activities, staff productivity, market share and size are the major determinants of the technical efficiency. Sufian (2007) conducted a study on domestic and foreign banks in Malaysia by using Deposits, Labour and Fixed Assets as inputs and Total Loans and total income as outputs. The study indicated that Domestic banks have gained more productivity improvement than foreign banks in Malaysia. The productivity of Gulf corporation council was measured by Ramakrishnan (2007) and only 15 out of 55 banks were rated as efficient banks. Sathye (2002) found a decline in the total factor productivity of Australian bank by 3.5\% during the study period of 1995-1999.

\subsection{Profitability analysis of banks}

The literature on profitability analysis of banks is mainly divided into two categories. One, which considers micro or internal variables affecting the 
profitability of banks and the other, which incorporates macro variables or external variables with micro variables to assess the profitability association with different variables. Hassan and Bashir analyzed the effect of micro and macro variables on the profitability of Islamic banks. The regression results showed that implicit and explicit taxes affect the bank performance measures negatively while favorable macroeconomic conditions impact performance measures positively. The results also indicated that high capital and loan-to-asset ratios lead to higher profitability of Islamic banks. Sufian and Chong (2008) investigated the profitability determinants of Philippines banks during 1990-2005. The empirical findings suggested that size, credit risk, and expense preference behaviour were negatively related to banks' profitability, while non-interest income and capitalisation had a positive impact. Chantapong (2005) studied the profitability of Thailand banks during crisis period and observed that foreign banks were more profitable than domestic banks. Athanasoglou et al. (2005) examined the effect of bank specific, industry specific and macroeconomic variables on the profitability of banks. All bank-specific determinants, with the exception of size, affect bank profitability significantly. However business cycles had a positive but asymmetric impact on the profitability of Greek banks. Goddard et al. (2004) investigated the profitability of European market banks. The results of the empirical analysis suggested that, despite the growth in competition in European financial markets, there was still significant persistence of profit from one year to the next. Further, unconvincing result between size and profitability was found but a positive relationship between capital adequacy ratio and profitability was observed during the study period. De Young and Rice (2004) in their study on U.S. commercial banks profitability found that increased non-interest income led increased profitability of banks but did not help in reducing the risk level of U.S. banks .Guru et al. (2002) examined the determinants of profitability of Malaysian banks during 1986-1995 and revealed a significant positive association between efficient expenses management and profitability but high interest ratio was negatively associated with the profitability of banks. In another study on European banks Molyneux and Thornton (1992) found a significantly negative relationship between the liquidity and profitability of banks. Also, the ownership structure of banks did not have any effect on the profitability of banks.

The above literature review makes it clear that there are numerous studies which evaluate the productivity or profitability one at a time. However, a detailed analysis on both productivity and profitability aspect is somewhat missing in the studied literature. Hence, the present study is an addition to the existing literature in that sense as both productivity and profitability are being assessed concurrently.

\section{Research Methodology}

Research is a worldwide accepted phenomenon for advancement of knowledge in every field of life. According to Rajasekar et al. (2013), it is an investigation of 
finding solutions to the scientific and social problems through objective and systematic analysis. There are two basic things required to conduct a research, the clarity of what to do and the right way to do that. So, it is important to form research objectives and then to apply scientific methods to achieve those objectives. So, this section discloses the different research objective, hypotheses and the methods used to achieve those objectives.

\subsection{Research Objectives}

The present study aims to assess the productivity and profitability of public and private sector banks in India. The present study also measures the different components of productivity and profitability over the period of ten years (2004-05 to 2013-14). The different determinants of productivity are also being assessed. One of the main objectives of the present study is to discover the effect of traditional and non-traditional activities on the profitability of the banking sector in India.

\subsection{Formulation of Research Hypotheses}

Based on the above stated objectives following hypotheses are framed. The public and private sector banks are the major contributor to the banking business in India. The public sector banks are mainly owned by the government and private sector bank's ownership is mainly in the hands of individuals and private institutions. So, due to differentiation in the ownership structure it is imperative to study the difference between the productivity of these two types of banks. The literature suggests mixed results on the aspect that either public sector banks are more productive than private sector banks or not. In 2014, there are 26 public sector banks and 20 private sector banks are functioning in India. So, $\mathrm{H}_{01}$ proposes public sector banks to be more productive than the private sector banks.

$H_{01}$ : The public sector banks are significantly better performer in terms of productivity than the private sector banks.

The main objective of the study is to measure the productivity of banks over the past ten years (2004-05 to 2013-14). Further, the time period is divided into two sub-periods i.e. 2004-05 to 2008-09 and 2009-10 to 2013-14. So, the assumption of next hypothesis is based on the division of this time period.

$H_{02}$ : There is no significant difference in the productivity of Indian banking sector in sub-period I (2004-05 to 2008-09) and sub-period II (2009-10 to 2013-14).

There is further division of public and private sector in India. The public sector is further divided into two group State bank group (SBG) and Nationalized group (NG). SB group comprises State Bank of India and its five subsidiaries banks and all other public sector banks are included in NB group. As the state bank of India is considered the largest bank in terms of assets with its subsidiaries, so, the 
assumption behind the $\mathrm{H}_{03}(\mathrm{a})$ is that the performance of SB group may be better than the NB group.

$H_{03 \text { (a): }}$ The productivity of State bank group (SBG) is significantly better than Nationalized group (NG) over the entire study period.

$H_{03}(b)$ : The productivity of old sector private banks and de novo banks is not significantly different over the entire study period.

Also, the private sector banks have two main groups. One is old sector private banks and another is de novo private sector banks. All the banks which are formed after 1996 are placed in the de novo bank group and the banks operating before 1996 reforms are termed as old private sector banks. The $\mathrm{H}_{03}(\mathrm{~b})$ is framed on the postulation that the main endeavor of the private sector banks is to provide consistent better service in all respects, subsequently, both groups seek to achieve higher productivity.

In literature, different determinants of productivity are studied such as size, risk, net interest income. One of the important variables which is said to positively relate to the productivity is size of banks. According to Delis and Papanikolaou (2009), generally, the effect of growing size on efficiency has been proved to be positive to a certain extent. However, for banks that become extremely large, the effect of size could be negative due to bureaucratic reasons. So, the next hypothesis is based on the relation between size and productivity.

$H_{04}(a):$ There is significantly positive relation between the size and productivity of banks i.e. larger banks tend to be more productive than the smaller banks.

Like size, the profitability may also be helpful to banks in getting more productivity, as, more profitable banks may use more advanced resources to increase its productivity. So, further, to test the significance of profitability on the productivity of banks following hypothesis is being framed.

$H_{04}$ (b): There is significantly positive relation between the profitability and productivity of banks i.e. more profitable banks are capable of being more productive.

The profitability is equally important for a bank like the productivity. In the past the main source of income for banks was considered from the net interest income which is also termed as spread (the difference between the interest income and interest expenses). But the present banking system is not restricted to the traditional activities of collecting deposits and allocating advances to the customers. These day banks are simultaneously involved in non-interest activities which may be termed as non-traditional activities or as diversification of activities. The one of the objectives of the present study is to find the effect of traditional and non-traditional activities on the profitability of banks. So, the following hypothesis is set, keeping in mind the changing scenario of banking activities. 
$H_{05}$ : The non-traditional activities or diversification significantly contribute more to the profitability of banks than traditional activities or spread.

\subsection{Sample Size and study period}

The sample size of present study includes all the public and private sector banks operating in India during the study period of 2004-05 to 2013-14. In total 46 (26 public and 20 private) banks are selected for the present study. The study period is further, divided into two sub periods, as, it is better to compare the performance in two different periods. Sub period I is from 2004-05 to 2008-09 and sub period II is from 2009-10 to 2013-14. While, the world economy was coming out from the crisis, so, it may be more useful to study and compare the productivity and profitability of banks in these two different time periods.

\subsection{Methodology}

As the main objective of the present study is to assess the determinants of productivity and profitability of banks, a two-stage approach is being used. In the first stage productivity and profitability is measured and in the second stage regression analysis is carried out to assess the effects of different variables on the productivity and profitability of banks. The present study utilizes linear programming method Data Envelopment Analysis based Malmquist Productivity Index to measure the productivity and its different components. Data Envelopment Analysis is a non-parametric method using a mathematical technique called linear programming (LP), which concerns with the allocation and utilization of limited resources (Wahidudin). The inception of DEA is termed from the seminal article by Farell (1957) on "The Measurement of Productive Efficiency". But the methodology gains its momentum from the work of Charnes et al. (1978). Initially, constant return to scale model was developed by Charnes, Cooper and Rhodes using different input and output. Then an extension in form of variable return to scale was done in further studies. Further, there are three approaches in the index numbers method which are Fischer index (1992), Tornqvist index (1936) and Malmquist index (1953). The Malmquist index approach has been applied in the study as it has certain advantages over the other two. According to Grifell Tatje and Lovell (1996), the Malmquist index does not require the profit maximization or cost minimization assumption. Secondly, it is the preferred method when inputs and outputs, price information is not available. Lastly, if panel data is available the productivity changes can be decomposed into technical efficiency change (also called the catching up index) and the technical change (also called the changes in best practice index). Its drawback is that it requires the computation of distance function. However, the linear programming technique of Data Envelopment Analysis (DEA) can be used to solve the problem (Sathye, 2002). There is also rule of thumb on the size of sample used in DEA. Cooper et al. (2007) provides two such rules that can be expressed as $n \geq \max \{m \times s ; 3(m+s)\}$ where $n=$ number of DMU, $\mathrm{m}=$ number of inputs and $\mathrm{s}=$ number of outputs. The first rule of thumb states that 
sample size should be greater than equal to product of inputs and outputs. While the second rule states that number of observation in the data set should be at least three times the sum of number of input and output variables. In the present study two inputs and three outputs are used, so, according to the rule of thumb minimum $(2+3) \times 3=15$ banks should form the sample of the study, whereas, a total of 46 banks constitute the sample size in the present study. The nonparametric Data Envelopment Analysis based Malmquist Productivity Index is applied in the present study to measure total factor productivity of banks. This application uses panel data to calculate indices of total factor productivity change, technological change, technical efficiency change, pure technical efficiency change and scale efficiency change (Krishnasamy et al., 2003). DEA was initially developed by Charnes et al. (1978) and further extended by Banker et al. (1984) and its first application to study the efficiency of bank branches was done by Sherman and Gold. Fare et al. (1994) specifies and output-based Malmquist productivity index as:

$$
M_{0}\left(y_{t+1}, x_{t+1}, y_{t}, x_{t}\right)=\left\{\frac{d^{t}\left(x^{t+1}, y^{t+1}\right)}{d_{0}^{t}\left(x^{t}, y^{t}\right)} \times \frac{d o^{t+1}\left(x^{t+1}, y^{t+1}\right)}{d_{0}^{t}\left(x^{t}, y^{t}\right)}\right\}^{1 / 2}
$$

The above equation represents the productivity of production points $\left(\mathrm{x}^{\mathrm{t}+1}, \mathrm{y}^{\mathrm{t}+1}\right)$ relative to the production point $\left(x^{t}, y^{t}\right)$, the value greater than 1 implies total productivity growth from period $t$ to the next period $t+1$, however the index is the geometric mean of the two outputs based Malmquist indices .The index uses period t technology and the other period $t+1$ technology. The above Malmquist productivity Index can be decomposed, according to Fare et al. $(1989,1992)$ as follows:

$$
\mathrm{M}_{0}\left(\mathrm{y}_{\mathrm{t}+1}, \mathrm{x}_{\mathrm{t}+1}, \mathrm{y}_{\mathrm{t}}, \mathrm{x}_{\mathrm{t}}\right)=\frac{d_{0}^{t}\left(x^{t+1}, y^{t+1}\right)}{d_{o}^{t}\left(x^{t}, y^{t}\right)} \times\left(\frac{d_{o}^{t}\left(x^{t+1}, y^{t+1}\right.}{d_{0}^{t+1}\left(x^{t+1}, y^{t+1}\right)} \times \frac{d_{0}^{t}\left(x^{t}, y^{t}\right)}{d_{0}^{t+1}\left(x^{t}, y^{t}\right)}\right)^{1 / 2}
$$

In above equation the term outside the brackets implies the measurement change in relative efficiency in the technical efficiency between periods of time i.e. between $(t)$ and $(t+1)$. On the other hand the terms inside the brackets indicates the geometry of the two ratios in the equation, which indicates the shift in technology of two units, in our case we refer to the commercial banks. This is to say the efficiency change is obtained by calculating the ratio of efficiency in $(t+1)$ period in proportion to efficiency in $(t)$ period. Again to obtain efficiency change and technological change we split the equation above, as shown below.

$$
\begin{gathered}
\text { Efficiency Change }=\frac{d_{o}^{t}\left(x^{t+1}, y^{t+1}\right)}{d_{0}^{t}\left(x^{t}, y^{t}\right)} \\
\text { Technological Change }=\left\{\frac{d_{o}^{t}\left(x^{t+1}, y^{t+1}\right)}{d_{0}^{t+1}\left(x^{t+1}, y^{t+1}\right)} \times \frac{d_{0}^{t}\left(x^{t}, y^{t}\right)}{d_{0}^{t+1}\left(x^{t}, y^{t+1}\right)}\right\}^{1 / 2} \text {--------- (iii) }
\end{gathered}
$$

In case of no significant change between periods of time, which can be illustrated by $\mathrm{x}^{\mathrm{t}}=\mathrm{x}^{\mathrm{t}+1}$, as well as $\mathrm{y}^{\mathrm{t}}=\mathrm{y}^{\mathrm{t}+1}$, then the MPI is equal to 1 . The Malmquist Total factor 
productivity can be obtained by solving a series of linear programming equations (Fare 1998, Worthington, 1999).

Subject to

$$
\left[D_{o}^{t}\left(x^{t}, y^{t}\right)\right]^{-1}=\max _{\theta \lambda} \theta
$$

Subject to

$$
\begin{gathered}
-y_{i t}+Y_{t} \lambda \geq 0 \\
\Theta_{x i t}-X_{t} \lambda \geq 0 \\
\lambda \geq 0
\end{gathered}
$$

$$
\left[D_{0}^{t+1}\left(y_{t+1}, x_{t+1}\right)\right]^{-1}=\max _{\theta \lambda} \theta
$$

Subject to

$$
\begin{gathered}
-y_{i t+1}+y_{t+1} \lambda \geq 0 \\
\theta x_{i t+1}-x_{t+1} \lambda \geq 0 \\
\lambda \geq 0 \\
{\left[D_{0}^{t+1}\left(y_{t}, x_{t}\right)\right]^{-1}=\max _{\theta \lambda} \theta}
\end{gathered}
$$

$$
\begin{gathered}
-y_{i t}+y_{t+1} \lambda \geq 0 \\
\theta x_{i t}-x_{t+1} \lambda \geq 0 \\
\lambda \geq 0 \text {--------- } \\
{\left[D_{0}^{t+1}\left(y_{t+1}, x_{t+1}\right)\right]^{-1}=\max _{\theta \lambda} \theta}
\end{gathered}
$$

$$
\begin{array}{r}
-y_{i t}+y_{t+1} \lambda \geq 0 \\
\theta x_{i t}-x_{t+1} \lambda \geq 0 \\
\lambda \geq 0
\end{array}
$$

\subsection{Specification of Input and Output variables}

The determination of productivity requires inputs and outputs. The choice of inputs and outputs is an intricate task as there is no consensus in the literature about the inputs and outputs to be used, especially in case of banking industry. There are mainly two approaches which are frequently used in the literature for selecting inputs and outputs for banks, these are, intermediation approach and production approach. The intermediation approach proposed by Sealey and Lindley (1977) treats banks as financial intermediaries that channelize the funds between depositors and creditors. The production approach which was developed by Benston (1965) treats banks as service providers and emphasized the use of deposits, labor and capital as the main inputs of banks. The input and output variables for the present study are selected on the basis of intermediation approach which is mainly used for the bank analysis in the literature. The two inputs for the present study are deposits and physical capital which is a proxy of fixed assets of banks and three outputs are advances, investment and non-interest income. Further, return on average assets (ROAA) is used as a proxy of the 
profitability of the banks during the study period. The determinants of productivity and profitability are assessed through regression model.

Following regression equations are formed for the analysis:

$$
\begin{aligned}
& \text { TFP }=\alpha_{0}+\beta_{1}(\text { ROAA })+\beta_{2}(\text { SPREAD })+\beta_{3} \text { (DIV) }+\beta_{4} \text { (MKTSHARE) }+\beta_{5}(\text { SIZE })+\beta_{6} \\
& (D U M 1)+\beta_{7}(D U M 2)+\varepsilon_{i t}
\end{aligned}
$$
$(D U M 1)+\beta_{7}(D U M 2)+\varepsilon_{i t}$

TECHCH $=\alpha_{0}+\beta_{1}($ ROAA $)+\beta_{2}\left(\right.$ SPREAD) $+\beta_{3}$ (DIV) $+\beta_{4}$ (MKTSHARE) $+\beta_{5}\left(\right.$ SIZE) $+\beta_{6}$ $(D U M 1)+\beta_{7}(D U M 2)+\varepsilon_{i t}$

ROAA $=\alpha_{0}+\beta_{1}($ SPREAD $)+\beta_{2}$ (DIV) $+\beta_{3}($ MKTSHARE $)+\beta_{4}($ SIZE $)+\beta_{5}\left(\right.$ DUM1) $+\beta_{6}$ $(D U M 2)+\varepsilon_{\text {it }}$

(Where, TFP $=$ Total factor productivity, EFFCH = Efficiency change, $\mathrm{TECHCH}=$ Technological change, SIZE = log (Total assets), ROAA = Return on average assets, SPREAD = Spread to total average assets, DIV = Diversification; MKTSHARE = Mkt. share of bank in total deposits of all the banks under study; Dum1 = takes value of 1 for sub period II; Dum2 = takes value of 1 if bank is private sector bank; $\alpha_{0}=$ constant; $\beta=$ coefficients to be determined; $\varepsilon_{i t}=$ disturbance term)

\subsection{Variables of the study}

The description and the manner of calculating the variables of the study are explained as under.

ROAA: The return on average assets is used as a proxy for the profitability of banks. The profit after tax is used to measure ROAA in the study.

ROAA $=$ Net Profit after tax/Total Average Asset

SPREAD: This is termed as traditional source of income for banks. Where, spread is calculated after deducting the interest expenses from interest income. It is also termed as net interest margin (NIM).

SPREAD $=$ Net Interest Income-Net Interest Expenses/Total Average Assets

DIV: The abbreviation for diversification is termed as DIV. These days' banks are not limited to the traditional functions like collecting deposits and dispersing advances. So diversification is the income earned from other sources like brokerage, commission and exchange functions by banks.

DIV= Non-Interest Income/Total Average Assets

MKTSHARE: The market share shows the business of banks in terms of its deposits.

The market share of deposits of an individual bank is calculated by the deposits of a bank divided by the total deposits of all banks under study. 
MKTSHARE $=$ Deposits of $i_{\text {th }}$ bank/Total Deposits of all Banks

SIZE: The log of total assets of a bank is used as a proxy of size of that bank.

$\mathrm{SIZE}=\log ($ Total Assets)

Further, two dummy variables are also used in the study. One is for the two different time periods and other is for the type of bank i.e. either public or private. DUM1 takes the value of 1 for the second sub-period and 0 otherwise and DUM2 takes the value of 1 for private sector bank and 0 otherwise.

\section{Analysis of Results}

The descriptive statistics of outputs and inputs of the study are disclosed in the Table 1.

Table 1: Descriptive statistics and correlation between inputs and outputs

\begin{tabular}{|c|c|c|c|c|c|}
\hline & \multicolumn{3}{|c|}{ Outputs (in millions) } & \multicolumn{2}{|c|}{ Inputs (in millions) } \\
\hline & Advances & Investments & $\begin{array}{l}\text { Non-Int. } \\
\text { Income }\end{array}$ & Deposits & $\begin{array}{c}\text { Physical } \\
\text { Capital } \\
\end{array}$ \\
\hline \multicolumn{6}{|l|}{ All Banks } \\
\hline Mean & 558941 & 501147 & 13675 & 964471 & 9173 \\
\hline Median & 227967 & 272514 & 5891 & 501473 & 4198 \\
\hline Maximum & 12098287 & 7567194 & 388092 & 13944085 & 80021 \\
\hline Minimum & 2646 & 3632 & 47 & 6630 & 57 \\
\hline SD & 1069487 & 750341 & 27453 & 1453786 & 11930 \\
\hline \multicolumn{6}{|l|}{ Public Sector } \\
\hline \multicolumn{6}{|l|}{ Banks } \\
\hline Mean & 760208 & 712543 & 16791 & 1378037 & 12121 \\
\hline Median & 348637 & 459078 & 8995 & 848509 & 7325 \\
\hline Maximum & 12098287 & 7567194 & 388092 & 13944085 & 80021 \\
\hline Minimum & 56935 & 63222 & 1510 & 135852 & 642 \\
\hline SD & 1296553 & 877182 & 31997 & 1726103 & 12505 \\
\hline \multicolumn{6}{|l|}{ Private } \\
\hline \multicolumn{6}{|l|}{ Sector Banks } \\
\hline Mean & 297201 & 226333 & 9625 & 426836 & 5341 \\
\hline Median & 87325 & 91955 & 2305 & 162550 & 1680 \\
\hline Maximum & 3387026 & 2256161 & 88132 & 3673375 & 47443 \\
\hline Minimum & 2646 & 3632 & 47 & 6630 & 57 \\
\hline SD & 573151 & 403575 & 19408 & 695067 & 9932 \\
\hline \multicolumn{6}{|c|}{ Correlation Analysis } \\
\hline Advances & 1.0000 & & & & \\
\hline Investments & $0.6260^{*}$ & 1.0000 & & & \\
\hline $\begin{array}{l}\text { Non-Int. } \\
\text { Income }\end{array}$ & $0.8580^{*}$ & 0.8029* & 1.0000 & & \\
\hline Deposits & $0.9270 *$ & $0.8586^{*}$ & $0.8974 *$ & 1.0000 & \\
\hline $\begin{array}{l}\text { Physical } \\
\text { Capital }\end{array}$ & $0.7822 *$ & $0.7773 *$ & $0.7882^{*}$ & $0.8462 *$ & 1.0000 \\
\hline
\end{tabular}


The data is presented for public and private sector banks and also for both the sector banks together. The table reveals that the public sector banks are much bigger than private sector banks in terms of advances, investment, deposits and physical capital. But the gap in terms of non-interest income is narrowed between the two sector banks, which show the increased inclination of private sector banks towards these activities. Further, the correlation between inputs and outputs is also shown in the table. High correlation is observed amongst the inputs and outputs which can be understandable with the rationale that a bank having more physical capital may be more able to gather more deposits and becomes more proficient in providing additional advances which leads to increased income.

So, the high correlated inputs and outputs may be more useful for the analysis of banking sector. The total factor productivity of public and private sector banks with their sub-groups is portrayed in the Table 2 . The productivity is presented for all the years under the study. The results show that private sector banks are more productive in both the sub-period.

\section{Table 2. Total factor productivity of banks over the years}

\begin{tabular}{|c|c|c|c|c|c|c|c|}
\hline Year & All Banks & \multicolumn{3}{|c|}{ Public Sector Banks } & \multicolumn{3}{c|}{ Private Sector Banks } \\
\hline & & SB group & NB Group & $\begin{array}{c}\text { Both } \\
\text { Groups }\end{array}$ & $\begin{array}{c}\text { Old Banks } \\
\text { Group }\end{array}$ & $\begin{array}{c}\text { de novo } \\
\text { Banks }\end{array}$ & $\begin{array}{c}\text { Both } \\
\text { Groups }\end{array}$ \\
\hline $2004-05$ & 0.956 & 0.940 & 0.998 & 0.984 & 0.890 & 0.979 & 0.918 \\
\hline $2005-06$ & 0.990 & 0.839 & 0.936 & 0.913 & 1.058 & 1.163 & 1.094 \\
\hline $2006-07$ & 1.008 & 1.112 & 0.969 & 1.009 & 1.045 & 0.970 & 1.018 \\
\hline $2007-08$ & 1.008 & 1.024 & 0.972 & 0.983 & 1.027 & 1.063 & 1.040 \\
\hline $2008-09$ & 1.015 & 1.024 & 0.982 & 0.992 & 1.065 & 1.011 & 1.046 \\
\hline $2009-10$ & 1.142 & 1.040 & 1.031 & 1.033 & 1.336 & 1.215 & 1.293 \\
\hline $2010-11$ & 1.028 & 1.027 & 1.035 & 1.032 & 1.046 & 0.981 & 1.023 \\
\hline $2011-12$ & 0.913 & 0.887 & 0.796 & 0.816 & 1.021 & 1.093 & 1.045 \\
\hline $2012-13$ & 1.014 & 1.022 & 1.002 & 1.005 & 1.005 & 1.060 & 1.024 \\
\hline $2013-14$ & 0.982 & 1.008 & 0.983 & 0.989 & 0.969 & 0.978 & 0.973 \\
\hline Geometric Mean & & & & & & \\
\hline $\begin{array}{c}\text { Sub-Period I I } \\
2005-2009\end{array}$ & 0.995 & 0.986 & 0.967 & 0.975 & 1.016 & 1.036 & 1.023 \\
\hline $\begin{array}{c}\text { Sub-Period } \\
\text { II2010-2014 }\end{array}$ & 1.015 & 0.996 & 0.955 & 0.973 & 1.072 & 1.064 & 1.069 \\
\hline $\begin{array}{c}\text { Whole } \\
\text { Period }\end{array}$ & 1.005 & 0.991 & 0.961 & 0.974 & 1.044 & 1.050 & 1.046 \\
\hline
\end{tabular}

(SB group= State Bank group, NB group= Nationalized Bank group, de novo bank group consists the banks formed after 1996 reforms)

Moreover, the private sector banks are more consistent in their productivity than public sector banks, as, in the eight years out of ten they have productivity score more than one which is an indication of their steady performance during the study period. Further, both public and private sector banks have performed their best in the year 2009-10 having productivity of 1.033 and 1.293 respectively. 
Additionally, State bank group (SBG) is better performer than the Nationalized group (NB) in terms of productivity, while in case of private sector banks de novo banks have overall performed better than the old private sector banks, yet old sector banks have performed better than the de novo banks in the second subperiod. Overall, a slight increase in the productivity is being observed for the banking sector (taking together the public and private sector banks) in the second sub-period over the first. Further, to get the more comprehensive picture on the total factor productivity and its components of Indian banking sector the descriptive statistics of TFP and components are presented in the Table 3.

The table discloses that the reason behind the decreased productivity of public sector banks in the second sub-period and the source for the improved productivity of private sector banks. The results show that the main cause of decreased productivity of public sector banks is due to technological change rather efficiency change in the second sub-period which eventually reduces the overall productivity of the banks under the group. The private sector banks on the other hand manage their efficiency level with the increased technological change which leads to the overall improvement in the productivity of these banks. To observe the significance between the results of total factor productivity and its components, statistical tests are applied, the results of which are shown in the Table 4. Two tests one is t-test and other is Mann-Whitney $U$ test is applied to know the significance of the results obtained above.

To observe the significance between the results of total factor productivity and its components, statistical tests are applied, the results of which are shown in the Table 4. Two tests one is t-test and other is Mann-Whitney $U$ test is applied to know the significance of the results obtained above.

Further, the significance is checked between public and private sector banks and also between their sub-groups. As the time period of the study is divided into two sub-periods, so, the significance of results between these two periods is also observed. A significant difference between the total factor productivity of public and private sector banks is being observed and the negative value indicates that private sector banks are more productive than public sector banks which leads to the non-acceptance of $\mathrm{H}_{01}$ which assumes public sector banks to be more productive than private sector banks. The main reason behind the productivity differences is mainly due to technological changes rather efficiency change.

Further, no significant difference is detected in the total factor productivity and its components between SB group and NB group which leads to the non-acceptance of $\mathrm{H}_{03}$ (a) which presumes the SB group to be more productive than NB group. Furthermore, the productivity of the old private sector banks and de novo banks is not found significantly different which leads to the non-rejection of $\mathrm{H}_{03}(b)$. 


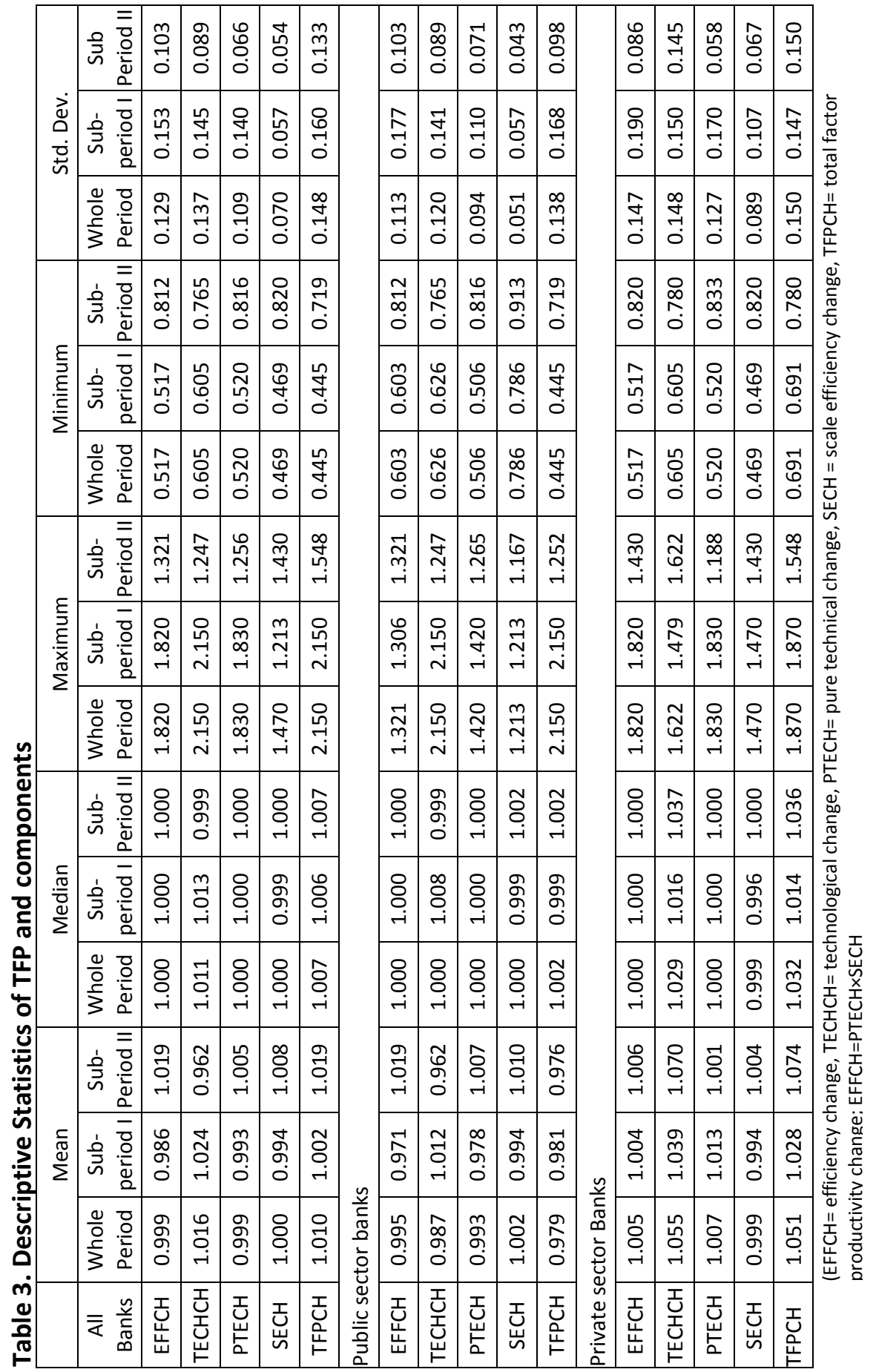


Table 4. Statistical test analysis of TFP and components

\begin{tabular}{|l|c|c|c|c|c|c|c|c|}
\hline & \multicolumn{2}{|c|}{ Public vs. Private } & \multicolumn{2}{c|}{$\begin{array}{c}\text { Sub-period } \\
\text { I vs. II }\end{array}$} & \multicolumn{2}{c|}{$\begin{array}{c}\text { SBI group vs. } \\
\text { NB group }\end{array}$} & $\begin{array}{c}\text { Old private banks vs. } \\
\text { de novo private banks }\end{array}$ \\
& t- test & $\begin{array}{c}\text { Mann- } \\
\text { Whitney } \\
\text { U test }\end{array}$ & t- test & $\begin{array}{c}\text { Mann- } \\
\text { Whitney } \\
\text { U test }\end{array}$ & t- test & $\begin{array}{c}\text { Mann- } \\
\text { Whitney } \\
\text { U test }\end{array}$ & t- test & $\begin{array}{c}\text { Mann- } \\
\text { Whitney } \\
\text { U test }\end{array}$ \\
\hline EFFCH & -0.803 & -0.324 & -2.352 & -1.112 & -0.500 & -0.138 & -0.791 & -1.160 \\
& $(0.422)$ & $(0.746)$ & $(0.019)$ & $(0.011)$ & $(0.960)$ & $(0.890)$ & $(0.430)$ & $(0.246)$ \\
\hline TECHCH & -5.430 & -5.142 & 1.189 & -1.397 & 0.805 & -1.602 & 0.157 & -0.200 \\
& $(0.000)$ & $(0.000)$ & $(0.235)$ & $(0.162)$ & $(0.422)$ & $(0.109)$ & $(0.875)$ & $(0.841)$ \\
\hline PTECH & -1.460 & -1.309 & -1.148 & -0.125 & 0.254 & -0.460 & -0.640 & -0.793 \\
& $(0.160)$ & $(0.150)$ & $(0.252)$ & $(0.901)$ & $(0.800)$ & $(0.645)$ & $(0.523)$ & $(0.428)$ \\
\hline SECH & 0.400 & -1.654 & -2.123 & -3.256 & -0.377 & -0.342 & -0.590 & -0.545 \\
& $(0.690)$ & $(0.120)$ & $(0.034)$ & $(0.001)$ & $(0.706)$ & $(0.733)$ & $(0.556)$ & $(0.586)$ \\
\hline TFPCH & -5.386 & -4.678 & -1.222 & -0.778 & 0.951 & -0.878 & -0.296 & -0.837 \\
& $(0.000)$ & $(0.000)$ & $(0.223)$ & $(0.436)$ & $(0.342)$ & $(0.380)$ & $(0.768)$ & $(0.403)$ \\
\hline
\end{tabular}

$(\mathrm{EFFCH}=$ efficiency change, $\mathrm{TECHCH}=$ technological change, $\mathrm{PTECH}=$ pure technical change, $\mathrm{SECH}=\mathrm{scale}$ efficiency change, $\mathrm{TFPCH}=$ total factor productivity change. The values in the parentheses are the $\mathrm{p}$ values of related test)

\subsection{Analysis of determinants}

As mentioned in the introduction part that productivity and profitability both are essential for banks for survival and growth, so it becomes important to evaluate which variables determine and affect these two. In this section different determinants of productivity and profitability are being analyzed. The impact of different variables like the size of banks in terms of total assets, the effect of traditional and non-traditional activities, and share of banks in terms of deposits etc. on the productivity and profitability of banks is being assessed. For this purpose regression models are being applied taking productivity and profitability as dependent variables and size, market share, spread and diversification as independent variables. Further, two dummy variables are also being introduced as independent variables, one is for the ownership structure i.e. either the public or private sector bank and other is for two different sub-periods. The prior condition to apply regression model is to test the stationarity of data. For this purpose Levin, Lin \& Chu (2002) unit root test is applied to check either the variables are stationary or not with the null hypothesis of data having a unit root. The results of the test are placed in the table 5. The results of unit root test lead to reject the null hypothesis of data having a unit root at $1 \%$ level of significance which show that data of different variables is robust for the further application of OLS model.

The correlation analysis of different variables is also measured to check the relationship among them. The table 6 is all about the results of correlation matrix of variables under study. 
Determinants of Productivity and Profitability of Indian Banking Sector: A Comparative study

Table 5. Result of Unit root test

\begin{tabular}{|l|c|c|c|}
\hline Variables & Statistics & P value & Result \\
\hline ROAA & -4.89205 & 0.000 & Reject $\mathrm{H}_{0}$ \\
\hline SPREAD & -6.74376 & 0.000 & Reject $\mathrm{H}_{0}$ \\
\hline DIV. & -5.87294 & 0.000 & Reject $\mathrm{H}_{0}$ \\
\hline MKT. SHARE & -11.8954 & 0.000 & Reject $\mathrm{H}_{0}$ \\
\hline SIZE & -14.2149 & 0.000 & Reject $\mathrm{H}_{0}$ \\
\hline EFFCH & -12.0877 & 0.000 & Reject $\mathrm{H}_{0}$ \\
\hline TECHCH & -12.8705 & 0.000 & Reject $\mathrm{H}_{0}$ \\
\hline PTECH & -20.5493 & 0.000 & Reject $\mathrm{H}_{0}$ \\
\hline SECH & -5.12962 & 0.000 & Reject $\mathrm{H}_{0}$ \\
\hline TFPCH & -12.6160 & 0.000 & Reject $\mathrm{H}_{0}$ \\
\hline
\end{tabular}

Table 6. Correlation analysis of different variables

\begin{tabular}{|c|c|c|c|c|c|c|c|c|c|c|}
\hline \multirow[b]{2}{*}{ Variables } & \multirow[b]{2}{*}{ ROAA } & \multicolumn{6}{|c|}{ MKTSHA } & \multirow[b]{2}{*}{ PTECH } & \multirow[b]{2}{*}{ SECH } & \multirow[b]{2}{*}{ TFPCH } \\
\hline & & SPREAD & DIV & $\mathrm{RE}$ & SIZE & EFFCH & TECHCH & & & \\
\hline ROAA & 1.000 & & & & & & & & & \\
\hline SPREAD & $\begin{array}{l}0.3828^{*} \\
(8.8597)\end{array}$ & 1.000 & & & & & & & & \\
\hline DIV & $\begin{array}{l}0.2945^{*} \\
(6.5886)\end{array}$ & $\begin{array}{l}0.1475^{*} \\
(3.1892)\end{array}$ & & & & & & & & \\
\hline $\begin{array}{l}\text { MKT } \\
\text { SHARE }\end{array}$ & $\begin{array}{c}0.0444 \\
(0.9512)\end{array}$ & $\begin{array}{l}-0.0639 \\
(-3.189)\end{array}$ & $\begin{array}{c}0.0919 * * \\
(1.9747)\end{array}$ & 1.0000 & & & & & & \\
\hline SIZE & $\begin{array}{c}0.1066^{* *} \\
(2.2921)\end{array}$ & $\begin{array}{l}-0.2164 \\
(-1.369)\end{array}$ & $\begin{array}{c}0.0919 * * \\
(1.9747)\end{array}$ & $\begin{array}{l}0.6664^{*} \\
(19.106)\end{array}$ & 1.000 & & & & & \\
\hline EFFCH & $\begin{array}{c}0.1197^{*} \\
(2.577)\end{array}$ & $\begin{array}{c}0.0311 \\
(0.6652)\end{array}$ & $\begin{array}{c}0.0948^{* *} \\
(2.036)\end{array}$ & $\begin{array}{c}0.0074 \\
(0.1595)\end{array}$ & $\begin{array}{c}0.0342 \\
(0.7314)\end{array}$ & 1.000 & & & & \\
\hline $\mathrm{TECHCH}$ & $\begin{array}{c}0.0249 \\
(0.5324)\end{array}$ & $\begin{array}{c}0.0229 \\
(0.4801)\end{array}$ & $\begin{array}{c}0.1421^{*} \\
(3.069)\end{array}$ & $\begin{array}{c}- \\
0.1031^{* *} \\
(-2.215)\end{array}$ & $\begin{array}{c}-0.1997^{*} \\
(-4.3585)\end{array}$ & $\begin{array}{c}-0.4016^{*} \\
(-9.376)\end{array}$ & 1.000 & & & \\
\hline PTECH & $\begin{array}{c}-0.0289 \\
(-0.6184)\end{array}$ & $\begin{array}{c}0.0214 \\
(0.4594)\end{array}$ & $\begin{array}{c}0.0568 \\
(1.2168)\end{array}$ & $\begin{array}{l}-0.0335 \\
(-0.715)\end{array}$ & $\begin{array}{c}-0.0559 \\
(-1.1989)\end{array}$ & $\begin{array}{l}-0.6675^{*} \\
(-19.163)\end{array}$ & $\begin{array}{l}-0.2680^{*} \\
(-5.9487)\end{array}$ & 1.000 & & \\
\hline SECH & $\begin{array}{c}0.1049 * * \\
(2.256)\end{array}$ & $\begin{array}{c}0.0058 \\
(0.1194)\end{array}$ & $\begin{array}{l}0.0759 \\
(1.629)\end{array}$ & $\begin{array}{l}0.04353 \\
(0.9316)\end{array}$ & $\begin{array}{l}0.0715 \\
(1.533)\end{array}$ & $\begin{array}{l}0.5519 * \\
(14.512)\end{array}$ & $\begin{array}{c}-0.2330^{*} \\
(-5.122)\end{array}$ & $\begin{array}{l}-0.0613 \\
(-1.313)\end{array}$ & 1.000 & \\
\hline TFPCH & $\begin{array}{l}0.1632^{*} \\
(3.537)\end{array}$ & $\begin{array}{l}0.0732 \\
(1.569)\end{array}$ & $\begin{array}{l}0.2121^{*} \\
(4.640)\end{array}$ & $\begin{array}{c}- \\
0.0923 * * \\
(-1.982)\end{array}$ & $\begin{array}{c}-0.1448^{*} \\
(-3.129)\end{array}$ & $\begin{array}{l}0.4792^{*} \\
(11.672)\end{array}$ & $\begin{array}{l}0.5655^{*} \\
(14.661)\end{array}$ & $\begin{array}{l}0.2970^{*} \\
(6.649)\end{array}$ & $\begin{array}{l}0.2759^{*} \\
(6.1379)\end{array}$ & 1.000 \\
\hline
\end{tabular}

$(*, * *, * * *$ indicate significance at $1 \%, 5 \%$ and $10 \%$ level respectively. The $t$-statistics are shown in the parentheses.

The correlation results reveal that return on average assets (ROAA) which is used as a proxy of profitability is positively and significantly correlated with the SPREAD and Diversification which shows that both traditional and non-traditional activities are important for profitability of banks. Also, bigger banks are more profitable than smaller banks as SIZE is significantly positive to profitability but smaller banks are more productive than bigger banks over the study period. Further, efficiency and 
productivity is also important for better profitability as both are positive and significant to return on average assets. An apparent relationship between SIZE and MKTSHARE is also observed which shows that a larger bank has more market share than a smaller bank. Further, market share is negative to productivity which states that smaller banks in terms of market size may be more productive.

The results of regression model about the different determinants of total factor productivity and its components are displayed in the table 7 . Both fixed and random effect model are applied and Hausman test is used to choose between the two models. The close observation to the results shows that profitability is although positive to productivity but not significantly which show that more profitable banks may or may not be productive too, which leads to the nonacceptance of hypothesis $\mathrm{H}_{04}$ (b) which states more profitable banks are more productive. Moreover, the size of banks and productivity is negatively associated. The significantly negative association of size and productivity reveal that smaller banks are more productive than larger banks, so, the hypothesis $\mathrm{H}_{04}$ (a) which conditions a positive relation between size and productivity stands to be rejected.

The result of relation between size and productivity are consistent with the results of Berger et al. (2009) and Tina Zhang and Wang (2014) for banks in China. Further, diversification of activities is more essential to productivity than spread which states that more diversification may lead the banks towards more productivity.

The insignificant positive outcome of dum1 variable which is used for the separation analysis between two sub-periods states that although productivity is better in the second sub-period but not significantly. The dum 2 variable shows that private sector banks are more productive than public sector banks. On the basis of Hausman test result, the results of random effect model are used for above analysis except for the total factor productivity for which results of fixed effect model are being used.

The determinants of profitability of banks are also measured and the results are shown in table 8 . The fixed effect model results are used for the analysis. The results disclose that both diversification and spread are imperative contributor to the profitability of banks as both are found significantly associated with the profitability, although, the contribution of diversification is more towards the profitability of banks.

The results show that one percent change in the diversification activities leads to forty two percent increase in the profitability of banks under study while twenty one percent boost is observed due to one percent increase in spread. Moreover, larger banks are more profitable than smaller banks but insignificantly. The result of dummy variables reveal that no significant difference is there between public and private sector banks profitability and also no difference is found in the profitability between the two different time periods, although, private sector banks are insignificantly better than public sector banks in profitability. 


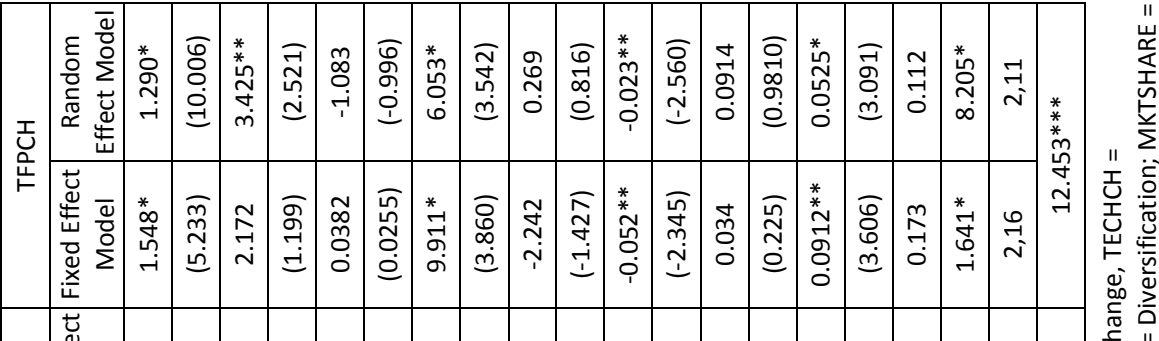

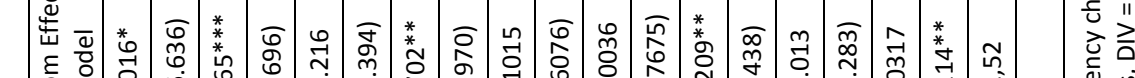
忈

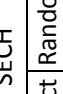

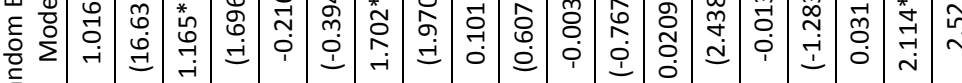

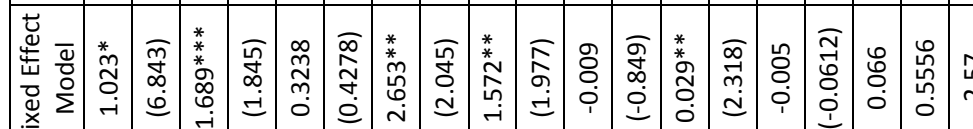

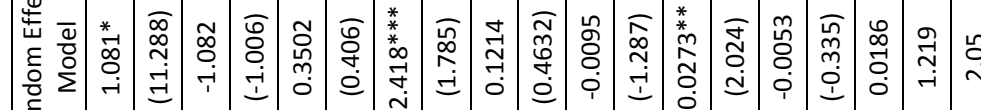
$\frac{1}{2}$

م

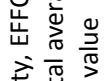

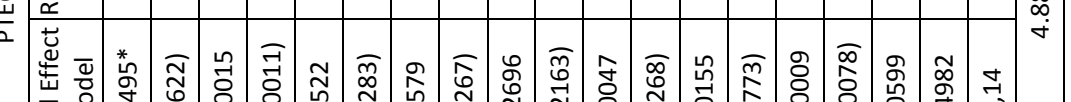

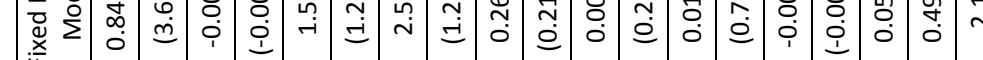
要峞

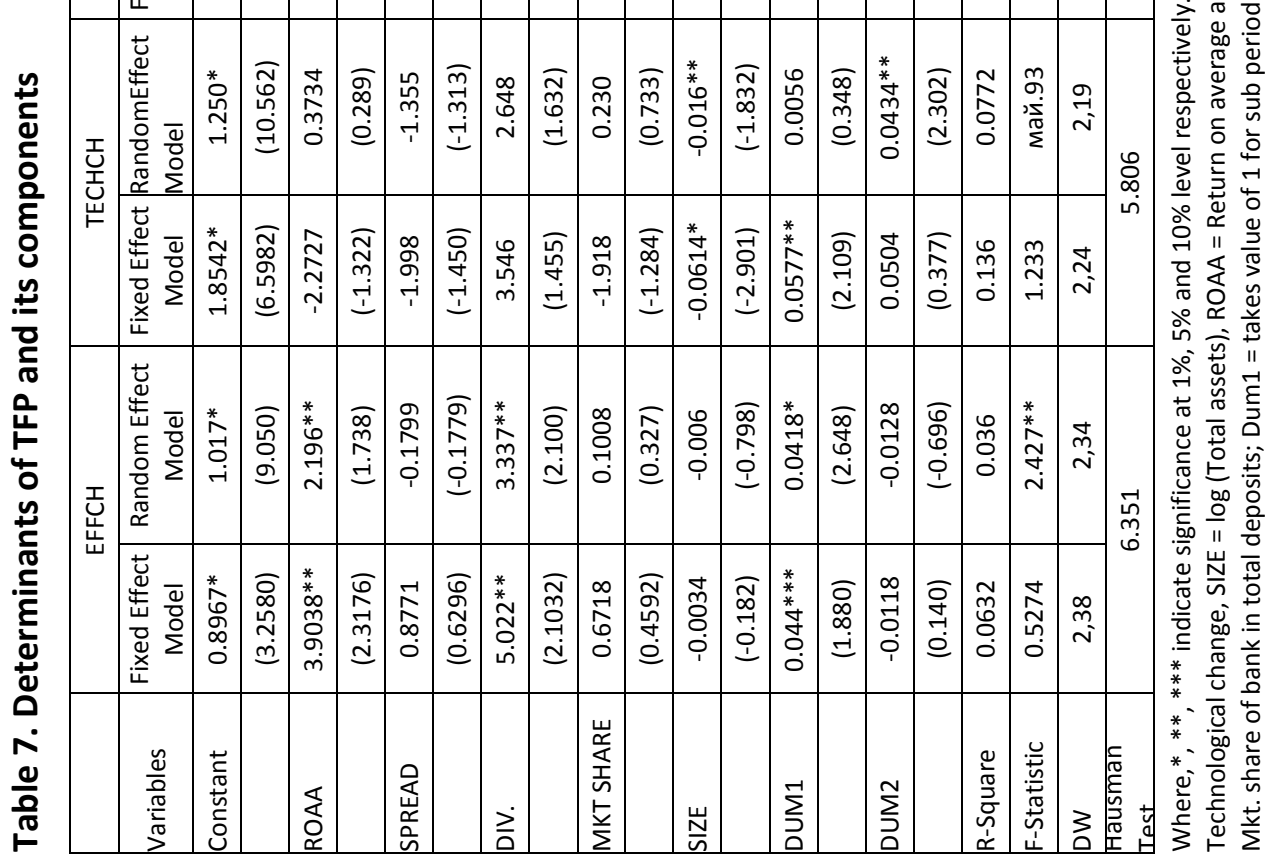


So, in the light of the above analysis, the hypothesis $\mathrm{H}_{05}$ which postulates more contribution of diversification activities than spread cannot be rejected.

Table 8. Determinants of Profitability of Banks

\begin{tabular}{|l|c|c|}
\hline Variables & Fixed Effect Model & Random Effect Model \\
\hline CONSTANT & $-0.01137(-1.4069)$ & $-0.0156^{*}(-2.735)$ \\
\hline SIZE & $0.0062(1.0241)$ & $0.0011^{* *}(2.328)$ \\
\hline DIV & $0.4198^{*}(6.255)$ & $0.3858^{*}(6.382)$ \\
\hline MKTSHARE & $-0.021(-0.4887)$ & $-0.0207(-1.085)$ \\
\hline SPREAD & $0.2074^{*}(5.225)$ & $0.2334^{*}(6.408)$ \\
\hline DUM1 & $0.0011(1.5006)$ & $0.00061(1.0382)$ \\
\hline DUM2 & $0.00377(0.8186)$ & $0.00093(0.8441)$ \\
\hline R-Squared & 0.5867 & 0.1645 \\
\hline F-Statistic & $11.322^{*}$ & $14.797^{*}$ \\
\hline DW & 1.391 & 1.31 \\
\hline Hausman Test & \multicolumn{2}{|c|}{$15.3328^{* *}$} \\
\hline
\end{tabular}

(Where, $*, * *, * * *$ indicate significance at $1 \%, 5 \%$ and $10 \%$ level respectively. The t-statistics are shown in parentheses. TFP = Total factor productivity, $\mathrm{EFFCH}=$ Efficiency change, $\mathrm{TECHCH}=$ Technological change, $\mathrm{SIZE}=\log$ (Total assets), ROAA = Return on average assets, SPREAD = Spread to total average assets, DIV = Diversification; MKTSHARE = Mkt. share of bank in total deposits; Dum1 = takes value of 1 for sub period II 0 otherwise; Dum2 = takes value of 1 if bank is private sector bank and 0 otherwise.)

\section{Conclusion}

The present paper is an attempt to analyze the productivity and profitability of public and private sector banks with their sub-groups over a study period of 200405 to 2013-14. The study also aims to discover the difference in the productivity of banks in two different sub-periods i.e. 2004-05 to 2008-09 and 2009-10 to 2013-14. For this purpose, Data Envelopment Analysis based Malmquist Productivity Index is applied to measure the productivity over the study period. Further, the different determinants of productivity are also being assessed to identify the effect of different variables on the productivity of banks particularly the size and profitability. As productivity and profitability both are essential for the banking firm for survival and growth, different determinants of profitability also form the part of the study. The main intention to study the profitability of the banks is to reveal either traditional activities or non-traditional activities are leading contributor towards the profitability.

The results of the study disclose that private sector banks are more productive than public sector banks over the whole study period. The main reason of more productivity of private sector banks is the better utilization of technology than the public sector banks. The productivity of banking sector of India is not found significantly different in the two sub-periods although the banks have performed better in the sub-period II (2009-10 to 2013-14). Further, no significant difference is found in the productivity of State bank group and Nationalized group over the 
study period. Also, the old private sector banks and de novo sector banks are not different in their productivity performance.

The results of different determinants of productivity reveal that although profitability is positively associated with total factor productivity but the association is insignificant. Further, diversification of activities lead to increased productivity, as, there is significantly positive association between them. In an important result of determinants, it is found that smaller banks are more productive than the larger banks in India, as, a significant negative association is observed between size and productivity. The insignificant positive outcome of dum1 variable which is used for the separation analysis between two sub-periods states that although productivity is better in the second sub-period but not significantly. The result of dum2 variable shows that private sector banks are more productive than public sector banks during the study period.

The determinants of profitability of banks are also measured and the results disclose that both diversification and spread are imperative contributor to the profitability of banks as both are found significantly associated with the profitability, although, the contribution of diversification (non-interest income) is more towards the profitability of banks. The results show that one percent change in the diversification activities leads to forty two percent increase in the profitability of banks, while twenty one percent boost is observed due to one percent increase in spread. Further, no significant difference in the profitability of the public and private sector banks is observed.

\section{Policy Implications and Future Research Prospects}

The outcomes of the study may be used by the policy makers to structure the future policies related to the productivity and profitability of the banks. The results of present study reveal that the main reason of less productivity between public and private banks is the use of technology. So, it may be the right time for the public sector banks to form policies regarding the better use of technology. The private sector banks may also make future policies to augment the efficiency part of their productivity. Further, the present study may be extended in many ways. The foreign banks may be included in the sample of the future studies. Moreover, the productivity may be determined through different inputs and outputs than used in the present study. Also, two different models consisting production and intermediation approach may also be used to measure the productivity of banks. The effect of productivity and its components on the profitability of banks may also be studied in the future studies. Further, DEA is a non-parametric method, so a comparative performance analysis can be done using parametric methods also. Malmquist Productivity Index provides the performance results but does not provide the reason which causes such performance, so, more elaborate studies can be conducted to find the cause and remedies for such performance. 


\section{References}

Athanasoglou, P. P., Brissimis, S. N., \& Delis, M. D. (2005). Bank specific, industry specific and macroeconomic determinants of bank profitability. Retrieved on September 20, 2014, from https://ideas.repec.org/p/bog/wpaper/25.html.

Arjomandi, A., Harvie, C., \& Valadkhani, A. (2012). An empirical analysis of Iran's banking performance. Studies in Economics and Finance, 29 (4), 287 - 300. http://dx.doi.org/10.1108/10867371211266928

Ataullah, A., \& Le, H. (2006). Economic reforms and bank efficiency in developing countries: the case of the Indian banking industry.Applied Financial Economics, 16, 653-63. http://dx.doi.org/10.1080/09603100500407440

Banker, Charnes \& Cooper (1984). Some models for estimating Technical and Scale efficiencies in Data Envelopment Analysis.Journal of Management Science, 30(9), 1078-1092. http://dx.doi.org/10.1287/mnsc.30.9.1078

Barman, R.B. (2007). Determinants of profitability of banks in India. 43rd Annual Conference of The Indian Econometric Society (TIES), Indian Institute of Technology, India.

Benston, G.J. (1965). Branch Banking and Economies of Scale. Journal of Finance20 (2), 312 331. http://dx.doi.org/10.1111/j.1540-6261.1965.tb00212.x

Berger, A., \& Mester, L. (1999). Inside the Black Box: What Explains Differences in Efficiencies of Financial Institutions. Journal of Banking and Finance 21, 895-947. http://dx.doi.org/10.1016/S0378-4266(97)00010-1

Berger, A.N., Hasan, I., \& Zhou, M. (2009). Bank ownership and efficiency in China: what will happen to the world's largest nation? Journal of Banking and Finance 33 (1), 113-130. http://dx.doi.org/10.1016/j.jbankfin.2007.05.016

Bhatia, A., \& Mahendru, M. (2015). Assessment of Technical Efficiency of Public Sector Banks in India Using Data Envelopment Analysis. Eurasian Journal of Business and Economics, 8(15), 115-140. http://dx.doi.org/10.17015/ejbe.2015.015.06

Casu, B., Cirardone, C., \& Molyneus, P. (2004). Productivity change in European banking: a comparison of parametric and non-parametric approaches.Journal of Banking and Finance, 28 (10), 2521-2540. http://dx.doi.org/10.1016/j.jbankfin.2003.10.014

Chantapong, S. (2005). Comparative Study of Domestic and Foreign Bank Performance in Thailand: The Regression Analysis.Economic Change and Restructuring, 38: 63-83. http://dx.doi.org/10.1007/s10644-005-4523-5

Chatzoglou, P.D., Diamantidis, A. D., Vraimaki, E., Polychrou, E. \& Chatzitheodorou, K. (2010). Banking productivity: an overview of the Greek banking system. Managerial Finance, 36(12), 1007-1027. http://dx.doi.org/10.1108/03074351011088423

Charnes, A., Cooper, W. W., \& Rhodes, E. (1978). Measuring the efficiency of decision making units. European journal of operational research, 2(6), 429-444. http://dx.doi.org/10.1016/0377-2217(78)90138-8

Delis, D. M., \& Papanikolaou, I. (2009). Determinants of bank efficiency: evidence from a semi-parametric methodology. Managerial Finance, 35(3), $260-275$. http://dx.doi.org/10.1108/03074350910931771 
De Young, R., \& Rice, T. (2004). Non-interest income and financial performance at US commercial banks. Financial Review, 39 (1), 101-127. http://dx.doi.org/10.1111/j.07328516.2004.00069.x

Farell, M. J. (1957). The measurement of Productive Efficiency. Journal of Royal Statistical Society Series, 253-281. http://dx.doi.org/10.2307/2343100

Goddard, J., Molyneux, P., \& Wilson, J. (2004). The profitability of European banks: A crosssectional and dynamic panel analysis. The Manchester School,72 (3), 363-381. http://dx.doi.org/10.1111/j.1467-9957.2004.00397.x

Grifell-Tatje, E. G., \& Lovell, C. A. K. (1996). Deregulation and Productivity Decline: The Case of Spanish Savings Banks. European Economic Review, 40, 1281303.http://dx.doi.org/10.1016/0014-2921(95)00024-0

Hausman, J.A. (1978). Specification tests in econometrics. Econometrica, 46(6), 1251-1271. http://dx.doi.org/10.2307/1913827

Hassan, M., \& Bashir, A. (2005). Determinants of Islamic Banking Profitability. Retrieved on September 20, 2014, from www.kantakji.com/media/3016/kabir bashir.pdf. http://dx.doi.org/10.3366/edinburgh/9780748621002.003.0008

Krishnasamy, G., Hanuum Ridzwa, A.,\& Perumal,V. (2003). Malaysian Post Merger Banks' Productivity: Application of Malmquist Productivity Index. Journal of Managerial Finance, 30(4), 63-74. http://dx.doi.org/10.1108/03074350410769038

Kumar, S., \& Gulati, R. (2008). Evaluation of technical efficiency and ranking of public sector banks in India. International Journal of Productivity and Performance Management, 57(7), 540 - 568.http://dx.doi.org/10.1108/17410400810904029

Kumar, S., \& Gulati, G. (2010). An examination of Technical, Pure and Scale efficiencies in Indian Public Sector Banks using Data Envelopment Analysis. Eurasian Journal of Business and Economics, 1(2), 33-69.

Levin, A., Lin, C.,\& Chu, J. (2002). Unit root tests in panel data: asymptotic and finite-sample Properties. Journal of Econometrics, 108(1), 1-24. http://dx.doi.org/10.1016/S0304-

4076(01)00098-7

Li-Hua, H., Hsing-Chin, H., Mei-Ai, C., \& Shyr-Juh, C. (2008). Effects of financial reform on productivity change. Industrial Management \& Data Systems, 108 (7), 867 - 886. http://dx.doi.org/10.1108/02635570810897973

Elyasiani, E., \& Mehdian, S.M. (1990). A nonparametric approach to measurement of efficiency and technological change: the case of large US commercial banks. Journal of Financial Services Research, 4, 157-68. http://dx.doi.org/10.1007/BF00352569

Guru, B. K., Staunton, J., \& Balashanmugam, B. (2002). Determinants of commercial bank profitability in Malaysia. Working Paper, Multimedia University.

Haung, L., \& Chen, Y. (2006). Does Bank Performance Benefit from Non-traditional Activities? A Case of Non-interest Incomes in Taiwan Commercial Banks.Asian Journal of Management and Humanity Sciences, 1(3), 359-378.

Malmquist, S. (1953). Index Numbers and Indifference Curves. Trabajos de Estatistica, 4(1), 209-42.http://dx.doi.org/10.1007/BF03006863

Molyneux, P., \& Thornton, J. (1992). Determinants of European bank profitability: A note.Journal of Banking and Finance, 16, 1173-1178.http://dx.doi.org/10.1016/03784266(92)90065-8 
Wahab, N. A., \& Rahim Abdul Rahman, A. (2012). Productivity growth of zakat institutions in Malaysia. Studies in Economics and Finance, 29 (3), 197 - 210. http://dx.doi.org/10.1108/10867371211246876

Sathye, M. (2002). Measuring Productivity Changes in Australian Banking: An Application of Malmquist Indices, Journal of Managerial Finance, 28(9), 48-59. http://dx.doi.org/10.1108/03074350210768068

Sealey, C. W., \& Lindley, J. T. (1977). Inputs, outputs, and a theory of production and cost at depository financial institutions, Journal of Finance, 32(4), 12511266.http://dx.doi.org/10.1111/j.1540-6261.1977.tb03324.x

Sufian F. (2007). Malmquist Indices of Productivity Change in Malaysian Islamic Banking Industry: Foreign vs. Domestic Banks, Journal of economic Cooperation, 28(1), 115-150.

Sufian, F., \& Chong, R. (2008). Determinants of bank profitability in a developing economy: empirical evidence from the Philippines. Asian Academy of Management Journal of Accounting andFinance, 4(2), 91-112.

Sharma, D., Sharma, A., \& Barua, M. (2012). Efficiency and productivity of banking sector: A critical analysis of literature and design of conceptual model. Qualitative Research in Financial Markets, 5 (2), 195-224.http://dx.doi.org/10.1108/QRFM-10-2011-0025

Heizer, J., \& Render, B. (1996). Production and Operations Management: Strategic and Tactical Decisions. Englewood Cliffs: Prentice-Hall.

Ho, M. T., \& Tripe, D. (2002). Factors influencing the performance of foreign owned banks in New Zealand. Journal of International Financial Markets, Institutions and Money, 12, 341-357. http://dx.doi.org/10.1016/S1042-4431(02)00018-5

Hanif Akhtar, M. (2010). Are Saudi banks productive and efficient? International Journal of Islamic and Middle Eastern Finance and Management, 3 (2), 95 - 112. http://dx.doi.org/10.1108/17538391011054354

Ramanathan, R. (2003). An Introduction to Data Envelopment Analysis. New Delhi: Sage.

Pasiouras F, \& Kosmidou K. (2007). Factors influencing the profitability of domestic and foreign commercial banks in the European Union. Research in International Business and Finance 21, 222-237. http://dx.doi.org/10.1016/j.ribaf.2006.03.007

Ramakrishnan, R. (2007). Performance of banks in countries of the Gulf Cooperation Council. International Journal of Productivity and Performance Management, 56(2), 137 - 154. http://dx.doi.org/10.1108/17410400710722635

Rezitis, A.N. (2006). Productivity growth in the Greek banking industry: a non-parametric approach. Journal of Applied Economics, 9, 119-38.

Tangen, S. (2004). Demystifying productivity and performance. Journal of Productivity and Performance Management, 54 (1), 34-46.http://dx.doi.org/10.1108/17410400510571437

Worthington, A. (1999). Malmquist Indices of Productivity Change in Australian Financial Services. Journal of International Financial Markets, Institutions and Money, 9(3), 303320.http://dx.doi.org/10.1016/S1042-4431(99)00013-X

Tina Zhang, X., \& Wang, Y. (2014). Production efficiency of Chinese banks: a revisit. Managerial Finance, 40(10), 969-986. http://dx.doi.org/10.1108/MF-05-2013-0115

Yeh, Q. (1996). The Application of Data Envelopment Analysis in Conjunction with Financial Ratios for Bank Performance Evaluation. The Journal of the Operational Research Society, 47(8), 980-988.http://dx.doi.org/10.1057/jors.1996.125 